\title{
置換ベンソイルイソシアナートの二量化, 三量化反応*1,1)
}

(昭 和 40 年 11 月 29 日受理)

柘植乙彦*2 水口隆三*3

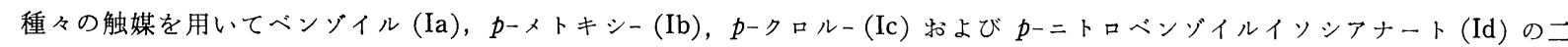
量化，三量化反応を検討した。トリエチルアミン触媒下に括いては，Iの置換基の電気的性質によって生成物の種類が大きく左右 され，Ia は $50^{\circ} \mathrm{C}$ で二量体， $80^{\circ} \mathrm{C}$ で 6-ケト-1,3,5-オキ+ジアジン体を主として与えるに反し，反応温度に関係なく Ib からは 三量体を，Ic，Id からは好収率でそれぞれ対応する 6-ケト-1,3,5-オキサジアジン体を生成した。ピリジニウム塩触媒下の反応で は置換基の効果は現われず，すべての昜合に 4-ケト-1,3,5-オキサジアジン体が得られた。しかし，ピリジン 1-オキシドを触媒 とした場合には置換基と反応温度の影響を5け, 二量体, 三量体あるいは 4-ケト-1,3,5-オキサジアジン体などが生成した。他方, ルイス酸型触媒の塩化第二スズを用いた場合には，Ia と Ib は三量体を与えたが，Ic と Id は反応しなかった。

このよ5な事実をもとにして各触媒下に扣ける生成物の生成機構を推定し, 本反応に怙けるベンジイルインシフナート類の反応

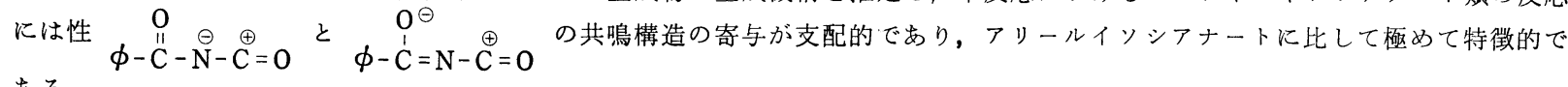
ある。

\section{1 緒言}

アリール技よびアルキルイソシアナートの反応については古く から多くの研究があり，とくに高分子化学の分野でウレタン系化 合物の重要性が認められて以来, イソシアナートの化学は急速に 進展した ${ }^{2,3)}$ 。しかし，アシルイソシアナートは主として酸塩化物 とシアン酸銀から合成されていたので ${ }^{4,5)}$, 近年までアシルイソシ アナートの反応はほとんど報告されていない。

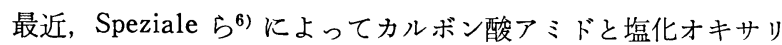
ルとの反応による簡便なアシルイソシアナートの合成法が見出さ れて以来, ベンゾイルイソシアナートの反応について注目すべき

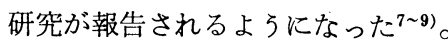

著者らは Speziale らの方法によってベンゾイル (Ia), $p$-メト キシ-(Ib), $p$-クロルー (Ic) 执よび $p$-ニトロベンゾイルイソシア ナート（Id）を合成し，これらベンゾイルイソシアナート類 (I ) の反応に拈いて, つぎの共鳴構造, とくに 1,4 -極性構造 (I-4) の寄与を期待して, 種々の触媒下の二量化, 三量化反応を検討し た。

*1 本報を「アシルイソシアナートに関する研究(第 1 報)」と する。

1）研究速報として報告（日化，86，325 (1965)).

*2 Otohiko TSUGE 九州大学生産科学研究所: 福岡书箱崎.

*3 Ryuzo MizUGUCHI 現在日本ペイント(株) 研究所：大阪 市大淀区大淀町.

2) R. G. Arnold, J. A. Nelson, G. J. Verbanc, Chem. Revs., 57, 47 (1957).

3) 向山, 有機合成協会誌, 19, 775 (1961).

4) O. C. Billeter, Ber., 36, 3218 (1903).

5) A. J. Hill, W. M. Degnan, J. Am. Chem. Soc., 62, 1595 (1940).

6) (a) A. J. Speziale, L. R. Smith, J. Org. Chem., 27, 4361 (1962) ; (b ) A. J. Speziale, L. R. Smith, ibid., 28, 1805 (1963).

7) L. A. McGrew, W. Sweeny, T. W. Campbell, V. S. Foldi, ibid., 29, 3002 (1964).

8) R. Neidlein, Angew. Chem., 76, 596 (1964).

9) R. Neidlein, Chem. Ber., 97, 3476 (1964).

$$
\begin{aligned}
& \phi-\stackrel{0}{\mathrm{C}}-\mathrm{N}=\mathrm{C}=\mathrm{O} \longleftrightarrow \phi-\stackrel{\mathrm{I}}{\mathrm{C}}-\mathrm{N}=\stackrel{\oplus}{\mathrm{C}}-\stackrel{\ominus}{\mathrm{O}} \\
& \text { I-1 I-2, }
\end{aligned}
$$

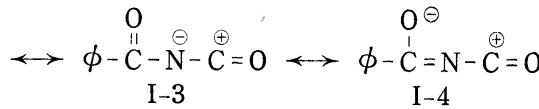

現在までアシルイソシアナートの二量体, 三量体は知られてい ないが, Terss ら ${ }^{10)}$ はピりジン中 Ia と塩化ベンゾイルの反応に よって 2, 6-ジフェニル-4-ケト-1, 3, 5-オキサジアジンを，また， 最近 Campbell 一派 ${ }^{7)}$ は Ia とホスホレンオキシド触媒との反応 で 2,6-ジフェニル-4-デヒドロベンザミド-1, 3, 5-オキサジアジ ンを得ている。前者は 2 分子の Ia, 後者は 3 分子の Ia から, そ れぞれ 1 分子の二酸化炭素が離脱した縮合物に対応するものであ る。

一般に, イソシアナート類の多量化触媒としては第三アミン, 第三ホスフィン類が用いられている。本研究で用いた触媒はトリ エチルアミン, 塩化 $N$-ベンゾイルあるいは $N$-ベンジルピリジ ニウム，ピリジン 1-オキシドおよび塩化第二スズである。なお， トリフェニルホスフィン, トリフェニルメチルホスホニウム塩扰 よびトリフェニルホスフィンオキシドなどを触媒として同様な反 応を試みたが，その触媒作用は弱いことがわかった。本報では主 として前者の五種類の触媒を用いた反応について述べる。

\section{2 結果および考察}

\section{$2 \cdot 1$ 置換ベンゾイルイソシアナート（I）の合成}

Speziale らの方法6) に準じて, 対応するベンザミドと塩化オキ サリルとの反応によってベンジイルー (Ia), p-メトキシ- (Ib), $p$-クロル- (Ic) 怙よび $p$-ニトロベンゾイルシアナート (Id)を合 成し, 収率, 物理的性質を表 1 亿示した。な特, 文献末知の I は, それぞれエタノールあるいは水との反応によって得られるウレタ ンおよびジベンゾイル尿素として確認し, それぞれの誘導体の融 点, 元素分析值を表 1 に併記した。

10) R. H. Terss, W. E. McEwen, J. Am. Chem. Soc., 76, 580 (1954). 
表 1 置換ベンゾイルイソシアナ一ト拈よびそのウレタン，尿素誘導体

\begin{tabular}{|c|c|c|c|c|c|c|c|c|c|c|c|c|c|c|c|c|c|c|c|}
\hline \multirow[t]{2}{*}{$\mathrm{R}$} & \multirow{2}{*}{$\begin{array}{l}\text { 収 率 } \\
(\%)\end{array}$} & \multirow{2}{*}{$\begin{array}{l}\text { 沸, 点 } \\
\left(\mathrm{C} /{ }^{2} \mathrm{~mm}\right)\end{array}$} & \multirow{2}{*}{${ }^{\text {融 }}$ ( $\left.\mathrm{C}\right)^{\text {点 }}$} & \multirow{2}{*}{$\begin{array}{l}\left.\nu_{\mathrm{NCO}^{\mathrm{a}}}\right) \\
\left(\mathrm{cm}^{-1}\right)\end{array}$} & \multirow{2}{*}{$\begin{array}{r}{ }^{2} \mathrm{Co}^{\mathrm{a})} \\
\left(\mathrm{cm}^{-1}\right)\end{array}$} & \multirow{2}{*}{$\left.{ }^{(\mathrm{C}}{ }^{\mathrm{C}} \mathrm{C}\right)^{\mathrm{f}}$} & \multicolumn{3}{|c|}{ 分析値(\%) } & \multicolumn{3}{|c|}{ 計算做 $(\%)$} & \multirow{2}{*}{${ }^{\text {融 }}$ (C) } & \multicolumn{3}{|c|}{ 分析值 $(\%)$} & \multicolumn{3}{|c|}{ 計算优(\%) } \\
\hline & & & & & & & $\mathrm{C}$ & $\mathrm{H}$ & $\mathrm{N}$ & $\mathrm{C}$ & $\mathrm{H}$ & $\mathrm{N}$ & & $\mathrm{C}$ & $\mathrm{H}$ & $\mathrm{N}$ & C & $\mathrm{H}$ & $\mathrm{N}$ \\
\hline $\mathrm{H}$ & 90 & $100 / 2 \mathrm{~b})$ & $28 \sim 29 b)$ & $2270 \mathrm{~b})$ & 1705 & 108 d) & & & & & & & $218^{e)}$ & & & & & & \\
\hline $\mathrm{OCH}_{3}$ & 79 & $143 / 25$ & 40 & 2260 & 1705 & 118 & 59.45 & 6.06 & 6.27 & 59.18 & 5.87 & 6.28 & 214 & 62.10 & 4.85 & 8.61 & 62.22 & 4.88 & 8.54 \\
\hline $\mathrm{Cl}$ & 92 & $140 / 35$ & 38 & 2250 & 1705 & 128 & 53.07 & 4. 49 & 6.17 & 52.80 & 4.40 & 6.16 & $\begin{array}{c}249 \\
\text { (尔解) }\end{array}$ & 53.45 & 3.08 & 8.54 & 53.44 & 2.97 & 8. 32 \\
\hline $\mathrm{NO}_{2}$ & 92 & $185 / 35$ & $\left.93^{c}\right)$ & 2260 & 1705 & 145 & 50.66 & 4.03 & 11.58 & 50.42 & 4.23 & 11.76 & $\begin{array}{c}223 \\
\text { (行解) }\end{array}$ & 50.38 & 2.87 & 15.63 & 50.27 & 2.79 & 15.67 \\
\hline $\begin{array}{l}\text { a) } \\
\text { b) } \\
\text { c) } \\
\text { d) } \\
\text { e) }\end{array}$ & 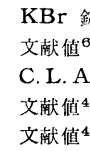 & $\begin{array}{l}\text { 銫剂にて測 } \\
\text { 8) : 沸点 } 9 \\
\text { Arcus, B. } \\
\text { 4) }: 110 \sim 1 \\
\text { 4) }: 208^{\circ} \mathrm{C}\end{array}$ & $\begin{array}{l}8 \mathrm{C} / 23 \mathrm{mn} \\
\mathrm{S} \text {. Pryda } \\
11^{\circ} \mathrm{C}\end{array}$ & $\begin{array}{l}\mathrm{mHg}, \mathrm{m} \\
\mathrm{l} \text { (J.Ch }\end{array}$ & $\begin{array}{l}\text { p } 25.5 \sim \\
\text { em. Soc. }\end{array}$ & $\begin{array}{l}26^{\circ} \mathrm{C}, \nu_{\mathrm{N}} \\
1957,1\end{array}$ & $\begin{array}{l}\text { co (ク } \\
091) k\end{array}$ & $\begin{array}{l}\text { ロホル } \\
\text { よると }\end{array}$ & $\begin{array}{l}\text { 溶液) } 2 \\
9 \sim 211^{\circ} \mathrm{C}\end{array}$ & $25 \mathrm{~cm}^{-}$ & & & & & & & & & \\
\hline
\end{tabular}

\section{$2 \cdot 2$ 置換ベンソイイイソシアナートの多量化反応}

I の置換基 $\mathrm{R} か ゙$ 電子吸引性であれば, 電子供与基の場合飞比し てイソシアナート基の炭素原子の求電子性は增大し，ルイス塩基 の攻撃を弓计易くなり，かつ， $\mathrm{R}$ 電気的性質の差異によって $\mathrm{I}$ （あるいはIにルイス塩基が配位した化合物）の共鳴構造の寄与 の程度が異なるので, $\mathrm{R}$ の種類によって違った構造の生成物を与 えることが期待される。

他方， Rが電子供与性であればイソシアナート基の窒素または 酸素原子の求核性は大となるので, ルイス酸型触媒の攻撃をうけ 易くなる。

$2 \cdot 2 \cdot 1$ トリエチルアミン触媒との反応 種々の溶媒中での I とトリエチルアミン触媒の反応の結果を表 2 亿示した。表 2 から わかるよ5に， Rの電気的性質によって生成物の種類，収率など は大きく影響される。

比較的低温での Ia の反応では，無色針状晶 (IIa), mp $164^{\circ} \mathrm{C}$ が主生成物である。本物質の元素分析値は $\mathrm{C}_{16} \mathrm{H}_{10} \mathrm{O}_{4} \mathrm{~N}_{2}$ に一致し, ベンゼン中水と加熱するとジベンジイル尿素とベンザミドの混合 物を与兄る。また，赤外スペクトル(図 1)*4 には 1815,1730 物 よび $1710 \mathrm{~cm}^{-1} に \nu_{\mathrm{C}=0}, 1600 \sim 1620 \mathrm{~cm}^{-1}$ に $\nu_{\mathrm{C}=\mathrm{N}}$ にもとつくく 吸收があり, 高波数領域 1815 と $1730 \mathrm{~cm}^{-1}$ の $\nu_{\mathrm{C}=0}$ はジケ トー1,3, 5-オキサジアジン環 の 6 -ケトと 4-ケト基にそれ ぞれ帚属できる。これらの事 実をもとにして，本物質は二 量体，2-フェニル-5-ベンジ イルー4, 6-ジケト-1,3,5-オキ サジアジン (IIa) であると推 定した。な拉, IIa は I-3 と I-4 型構造の付加体に相当し ている。

一方, 反応温度 $80^{\circ} \mathrm{C}$ では 無色針状晶(IIIa), mp $184^{\circ} \mathrm{C}$ が得られ，とくにへキサンを 溶媒とした場合に收率がよ い。本物質の元素分析値は 2 分子の Ia から 1 分子の二酸 化炭素が離眖した $\mathrm{C}_{15} \mathrm{H}_{10} \mathrm{O}_{2} \mathrm{~N}_{2}$ に一致し，加水分解㳊っって

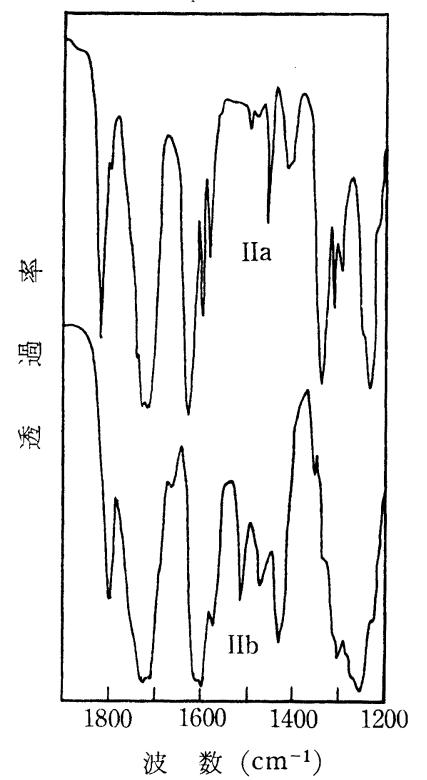

図 1 二量体 (IIa, IIb) の赤外吸 収スペクトル
ジベンザミドを与兄る。また，四 2 亿示した本物質の赤外スペク トルは特微的であって, $1770 \mathrm{~cm}^{-1}$ に強い $\nu_{\mathrm{C}=0}$ と $1580 \sim 1620$ $\mathrm{cm}^{-1}$ に数本にスプリットした $\nu_{\mathrm{C}=\mathrm{N}}$ の吸收が認められ，これら $\nu_{\mathrm{C}=0}$ と $\nu_{\mathrm{C}=\mathrm{N}}$ の吸收強度と波数の相関関倸は， $\alpha-$ ピロン体に抢 ける $\nu_{\mathrm{C}=\mathrm{O}}$ と $\nu_{\mathrm{C}=\mathrm{C}}$ のそれらの関係 ${ }^{11)}$ とよい類似性を示してい る。これらの事実をもとにして，本物質は 2,4 -ジフェニル-6-ケ ト-1,3,5-オキサジン (IIIa) であろらと推定した。な就，IIIa は 先に Terss ら ${ }^{10)}$ とっって報告された 2,6-ジフェニルー4-ケト-1, 3, 5-オキサジアジンと異性体の関倸にあって，後述の上5にこれ ら両異性体の $\nu_{\mathrm{C}=0}$ と $\nu_{\mathrm{C}=\mathrm{N}}$ の強度と波数の関係は, それぞれ $\alpha$ と、 $\gamma$-ピロン体の $\nu_{\mathrm{C}=0}$ と $\nu_{\mathrm{C}=\mathrm{C}}$ の関係とそれぞれよい類似性を示 していることは，IIIa の構造を支持するるのである。

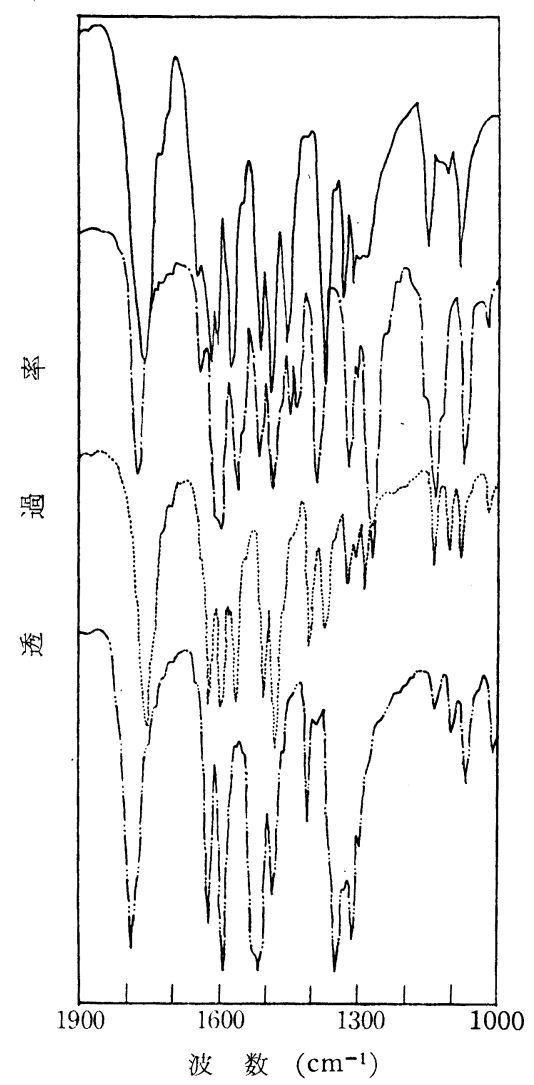

図 2 2, 4-ジアリール-6-ケト-1, 3, 5-オキサジアジン（III） の赤外吸収スペクトル

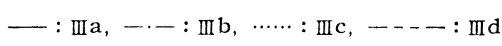

11）“赤外線吸収スペクトル第 7 集”, 南汇堂 (1959) p. 106

*4 本報の赤外スペクトルは $\mathrm{KBr}$ 錠剤にて測定。 
また， $80^{\circ} \mathrm{C}$ の反㐫で Va，VIa が主生成物である場合がある が，これら化合物は元素分析值，赤外スペクトルおよびそれぞれ の標品との同定によってトリベンザミド $(\mathrm{Va})$, トリフェニル-sトリアジン (VIa) であった。IIaをジオキサン中トリエチルアミ ンと加熱するとVaを，IIIaをべンゼン中加熱するのみで VIa が好収率で生成するので，本反応に打けるVa，VIa の生成は二 次的なるのと考光られる。

つぎに電子供与基をもつ Ib の反応に拈いては，反応条件に余 り左右されずに比較的低収率で無色針状晶 (IVb), mp $222^{\circ} \mathrm{C}$ (分 解）が生成する。本物質の赤外スペクトル（図 3 ）には, 1740 $\mathrm{cm}^{-1}$ に環内 $\nu_{\mathrm{C}=0}, 1710 \mathrm{~cm}^{-1}$ にベンゾイル基の $\nu_{\mathrm{C}=0}$ に帰属さ れる吸収がそれぞれ認められ るが， $\nu_{\mathrm{C}=\mathrm{N}}$ 吸収は現われて いない。かつ, シアヌレート 環にもとづく吸収を除くと対 応するトリベンザミドの赤外 スペクトルによく類似し, 元 素分析値からす本物質は三量 体，トリ（pーメトキシベンゾ イル)イソシアヌレート(IVb) であろうと推定される。

他方, 電子吸引基を的 Ic と Id の場合には, 表 2 に 示したように反応条件にかか わりなく高収率で，それぞれ 無色板状晶(IIIc), $\mathrm{mp} 240^{\circ} \mathrm{C}$ (分解), 淡黄色針状晶 (IIId), $\mathrm{mp} 230^{\circ} \mathrm{C}$ (分解) が得られる。 これら化合物は, 元素分析值 扣よび IIIa の赤外スペクト ルとの類似性から(図 2)，そ

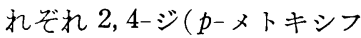
ェニル)-(IIIc), 2, 4-ジ ( $p$ ニトロフェニル) $-6-$ ケ -1 , 3,5-オキサジアジン(IIId) で あると推定した。

このよ5にRの電気的性質 によって生成物の種類や収率 が大きく影響されるが，これ

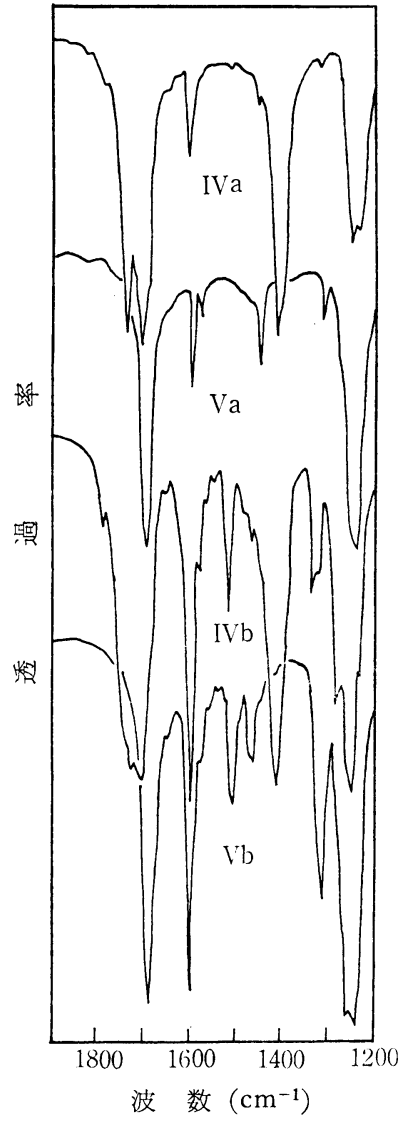

図 3 三翼体 (IVa, IVb) 打よび トリベンザミド $(\mathrm{Va}, \mathrm{Vb})$ の 赤外吸収スベクトル

表 2 I とトリェチルアミン触媒との应㐫

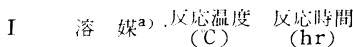
牛:成物の收讋 $(\%)$

\begin{tabular}{|c|c|c|c|c|c|c|}
\hline B & 50 & 20 & 50 & - & - & - \\
\hline B & 80 & 20 & - & + & - & 46 \\
\hline $\mathrm{CH}$ & 50 & 20 & yo & - & - & - \\
\hline $\mathrm{CH}$ & 80 & 20 & - & 9 & - & 43 \\
\hline $\mathrm{H}$ & 50 & 20 & 40 & - & - & - \\
\hline $\mathrm{H}$ & 遇 流 & 20 & -- & 79 & -- & 10 \\
\hline $\mathrm{E}$ & 邆 流 & 20 & 85 & - & - & - \\
\hline B & 50 & 20 & - & - & 23 & - \\
\hline$B$ & 80 & 20 & - & - & 23 & - \\
\hline $\mathrm{CH}_{\mathrm{H}}$ & 50 & 20 & - & - & 37 & $\ldots$ \\
\hline $\mathrm{CH}_{\mathrm{H}}$ & 80 & 20 & - & + & 47 & $\cdots$ \\
\hline b ) & b) & $1 \sim 3$ & - & $90 \sim 93$ & - & 一 \\
\hline b ) & b) & $1 \sim 3$ & - & $90 \sim 100$ & -- & - \\
\hline
\end{tabular}

a) $\mathrm{B}:$ ベンゼン, $\mathrm{CH}:$ シクロヘキサン, $\mathrm{H}: n$-ヘキサン, $\mathrm{E}:$ エ エルエーテル

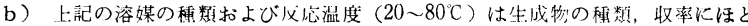
んど影響なし。

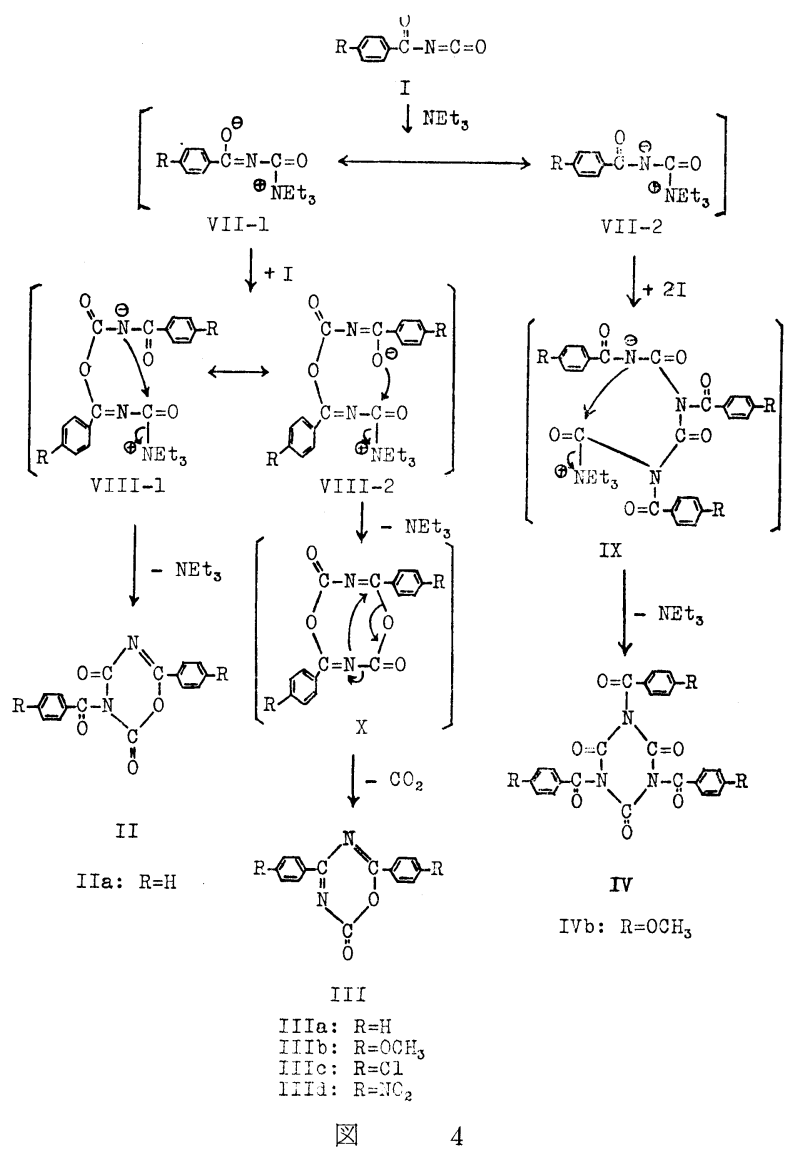

らの現象はつぎのように説明できる。ただし，ここで Va，VIa の生成は二次的なものであるので除外する。

図4に示したように，本反応に拈けるIIa，IIIa〜IIId 括よび IVb の生成はそれぞれ VII-1 $\rightarrow$ VIII-1 $\rightarrow$ II, VII $-1 \rightarrow$ VII $-2 \rightarrow \mathrm{X} \rightarrow$ III 特よび VII-2 $\rightarrow \mathbb{X} \rightarrow \mathrm{N}$ の経路によると考えた。すなわち I と トリエチルアミンの配位化合物 $(\mathrm{VI}) * 5$ には, 数種の極限構造が考 えられるが，VIは主として極限構造 VI - 1 と VI -2 の共鳴混成体 からなるとした。ここで， $\mathrm{R} か ゙$ 電子吸引性の場合にはアシル基の カルボニル炭素原子の求電子性は增大して隣接窒素原子からの電 子の移動が容易となって VI-1 構造, Rが電子供与性であればこ のような電子の移動は抑兄られて VI -2 構造の寄与がそれぞれ大 となる。

VI-1 がさらに 1 分子のIに配位した化合物（VIII）にも多くの極 限構造が考光られるが，二量体（II）は I -3 と I -4 構造の極性 付加体の構造をもつので, VII-1 構造から触媒の離脱と同時に安 定な六員環を形成して生成し，III 6-ット-1,3,5-オキサジアジ ン環すなわち，2 分子の I-4 構造から脱炭酸した縮合物である から，VIII-2 構造からまず，脱触媒して八員環中間体 (X) が生成 し，ついで脱炭酸により六員環構造をもつ而が生成したものと考 えた。

電子吸引基をもつ Ic，Id の場合に好収率で III みが得られる が， Rが電子吸引性であればルイス塩基のイソシアナート基の㷇 素原子への攻撃が容易であり, かつ VI, UII に打いては VI-1, UII-

*5 M. Pestmer ら (Angew. Chem., 72, 612 (1960)) はフ ェ. ニルイソシアナートと第三アミンとが型の付加体を生成 することを赤外スペクトルから認めている。 
2 構造の寄与がそれぞれ大となることから理解できる。

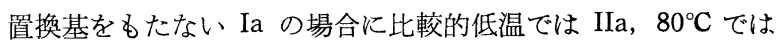
IIIa が主生成物であるが, このことは低温では VII-1 構造, 高混 では VIII-2 構造の寄与が大であることを示している。

他方， $\mathrm{R} か ゙$ 電子供与基の場合には上述のように $\mathrm{UI}-2$ 構造の答 与が優勢であり, 三量体 $(\mathrm{N})$ は 3 分子の I -3 構造の付加体であ るので，VI-2 にさらに 2 分子のI が配位した構造 $(\mathbb{X})$ から脱触 媒，六員環形成の経路によって，IVbは生成したものと考えられ る。な拉，IVb の収率が低いのはIb ののリエチルアミンの攻 撃が弱いためであろう。

トリフェニルホスフィンを触媒とした場合には, トリエチルア ミンに比して求核性が弱く, キシレン溶媒中 $120^{\circ} \mathrm{C}, 20$ 時間反応 して Ic，Id の場合にのみ IIIc，IIId をそれぞれ 23，16\% 収率 で与竞たにすぎなかった。

2.2.2 ピリジニウム塩触媒との反応 Terss ら ${ }^{10)}$ はピリジン 中 Ia と塩化ベンゾイルとを反応させ*6, 無色針状晶, $\mathrm{mp} 158^{\circ} \mathrm{C}$ を $22 \%$ 収率で得，本物質は 2,6 -ジフェニル-4-ケト-1, 3, 5-才 キサジアジン (XIa) であろうと推定している。

著者らは $N$-ベンゾイルピリジニウム塩のほかに $N$-ベンジル 体をIa と反応して比較的好収率で, Terss らと同一物質を得 た。また，Ib〜Id についても同様な反応を行ない，その結果を表 3 に示した。

\begin{tabular}{|c|c|c|}
\hline I & ピリジニウム塩 & 生成物 (XI)の収率(\%) \\
\hline I $\mathbf{a}$ & 塩化 $N$-ベンヅィル & $51 \sim 66$ \\
\hline I a & 聕化 $N$-ベンゾイル & 70 \\
\hline I b & 倎化 $N$-ベンゾイル & 23 \\
\hline I c & 塭化 $N$-ベンソ゚イル & 86 \\
\hline Id & 盐化 $N$-ベンゾイル & 50 \\
\hline
\end{tabular}

さて, 本反応で得られた生成物の元素分析值はいずれの場合に も2 分子の対応するIから 1 分子の二酸化炭素が離脱したものに 一致し，酸加水分解によってそれぞれ対応する尿素体を与える。 また，図 5 に示したこれら化合物の赤外スペクトルは図 2 に示し たのそれらと対象的である。すなわち，1710１730 $\mathrm{cm}^{-1}$ に強 度の弱い $\nu_{\mathrm{C}=0}\left(1890 \mathrm{~cm}^{-1}\right.$ 付近にスプリットして認められること あある）と $1730 \sim 1750 \mathrm{~cm}^{-1}$ に異常に強い $\nu_{\mathrm{C}=\mathrm{N}}$ の吸収が現わ れ，さらに後者の吸収は $1550 \sim 1600 \mathrm{~cm}^{-1}$ 領域に数本にスプリッ トして認められる。これら $\nu_{\mathrm{C}=0}$ と $\nu_{\mathrm{C}=\mathrm{N}}$ の強度, 波数の相関関 係は $\gamma$-ピロン体の $\nu_{\mathrm{C}=0}$ と $\nu_{\mathrm{C}=\mathrm{C}}$ のそれらとよい類似性を示し ている(1)。これらの事実は本物質は III の異性体の 2,6-ジアリー ルー4-ケト-1, 3, 5-オキサジアジン (XIa〜XId) であることを示す ものである。

な拈，トリフェニルメチルホスホニウム塩を触媒とした場合に は，全く反応は起こらなかった。

$2 \cdot 2 \cdot 3$ ピリジン 1-オキシド触媒との反応 上述のトリエチル アミンとピリジニウム塩の中間的性質を現わすと考えられるピリ ジン 1-オキシド触媒との反応をベンゼン中で行ない，その結果 を表 4 亿示した。

表 4 から分るよ5に, 本反心机いても $\mathrm{R}$ の電気的性質や反心 温度によって生成物が大きく左右される。すなわち，室温での反 応では Ia は二量体 (IIa) と微量の 4-ケト-1,3,5-オキサジアジ

*6 Terss らは反応中途で微量の水を加えているが，著者らは 無水の状態で行なった。

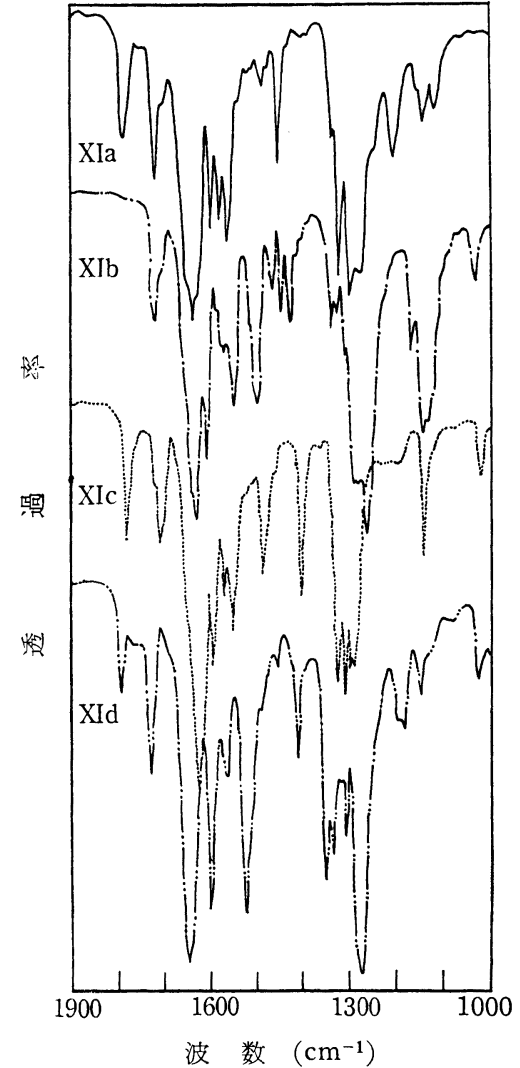

図 5 2, 6-ジアリールー4-ケト-1, 3,5-オキサジアジン (X) の赤外吸収スペクトル

表 4 I とピリジン 1ーオキシドとの反灾

\begin{tabular}{|c|c|c|c|c|c|}
\hline \multirow{2}{*}{ I } & \multirow{2}{*}{$\begin{array}{l}\text { 反灾湍度 } \\
\text { (C) }\end{array}$} & \multicolumn{4}{|c|}{ 生成物の收率（\%） } \\
\hline & & II & $\mathbb{N}$ & $\mathrm{V}$ & $\mathrm{XI}$ \\
\hline \multirow{2}{*}{ I $\mathbf{a}$} & 室 温 & 20 & $\overline{86}$ & - & + \\
\hline & $\begin{array}{l}50 \\
80\end{array}$ & $\overline{-}$ & 86 & $\overline{20}$ & $\bar{z}$ \\
\hline \multirow[b]{2}{*}{ I b } & 室温 & 60 & - & - & - \\
\hline & $\begin{array}{l}50 \\
80\end{array}$ & 43 & = & $\bar{z}$ & $\bar{z}+x+x+$ \\
\hline \multirow{2}{*}{ I c } & 室 温 & - & - & $\overrightarrow{1}$ & 16 \\
\hline & $\begin{array}{l}50 \\
80\end{array}$ & 二 & 二 & $\begin{array}{l}42 \\
71\end{array}$ & $\begin{array}{l}11 \\
+\end{array}$ \\
\hline \multirow[b]{2}{*}{ I d } & 室温 & - & - & 80 & - \\
\hline & $\begin{array}{l}50 \\
80\end{array}$ & $=$ & $=$ & $\begin{array}{l}81 \\
96\end{array}$ & \pm \\
\hline
\end{tabular}

ン（XIa）を与えるが， $50^{\circ} \mathrm{C}$ の反応では上記触媒との反応で生成 しなかった無色針状晶（IVa)， mp $261^{\circ} \mathrm{C}$ (分解) が好収率で得 られた。本物質は元素分析值执よびさきに得た三量体(IVb)の赤 外スペクトルとの対比から(図 3 )，三量体トリベンゾイルイソシ アヌレート(IVa) であろうと推定した。しかし，さらに高温での 反㐫では IIa の分解生成物のトリベンザミド(Va)が得られるに すぎない。

電子供与基をもつ Ib の場合には，反応温度が比較的低いとき に無色針状晶 (IIb)， mp $125 \sim 135^{\circ} \mathrm{C}$ (分解) が生成した。本物 質は IIa と同樣な化学的挙動を示し，赤外スペクトル（図 1 ）抒 よび元素分析值から二量体，2-p-メトキシフェニル-5-p-メトキ シベンゾイル-4, 6- ジケト-1, 3, 5-オキサジアジン (IIb) であろ と推定した。

他方, 電子吸引基をるつ Ic と Id からは微量のそれぞれ対応 する 4-ケト-1, 3, 5-オキサジアジン体 (XIc, XId) と二量体から の二次的生成物である対応するトリベンザミド $(\mathrm{Vc}, \mathrm{Vd})$ が多量 
生成する。

な拉, トリフェニルホスフィンオキシド触媒下, キシレン中, $140^{\circ} \mathrm{C}$ に加熱してもIは反応しなかった。

このよ5にピリジン 1-オキシドを用いた場合，6-ケト-1, 3, 5オキサジアジン（III）は全く生成せず，二量体（II)，三量体 (N) または 4-ケト-1, 3, 5-オキサジアジン (XI) が得られる。

本触媒下の反応経路を図 6 に示した。すなわち，I とピリジン 1ーオキシド $(\mathrm{Py} \oplus-\mathrm{O} \ominus$ で表わす) との配位化合物 $(\mathrm{XII}) * 7$ には, 数 種の極限構造が考えられるが，XIは主とてて XII-1 とXII-2 の共 鳴混成体からなるとした。

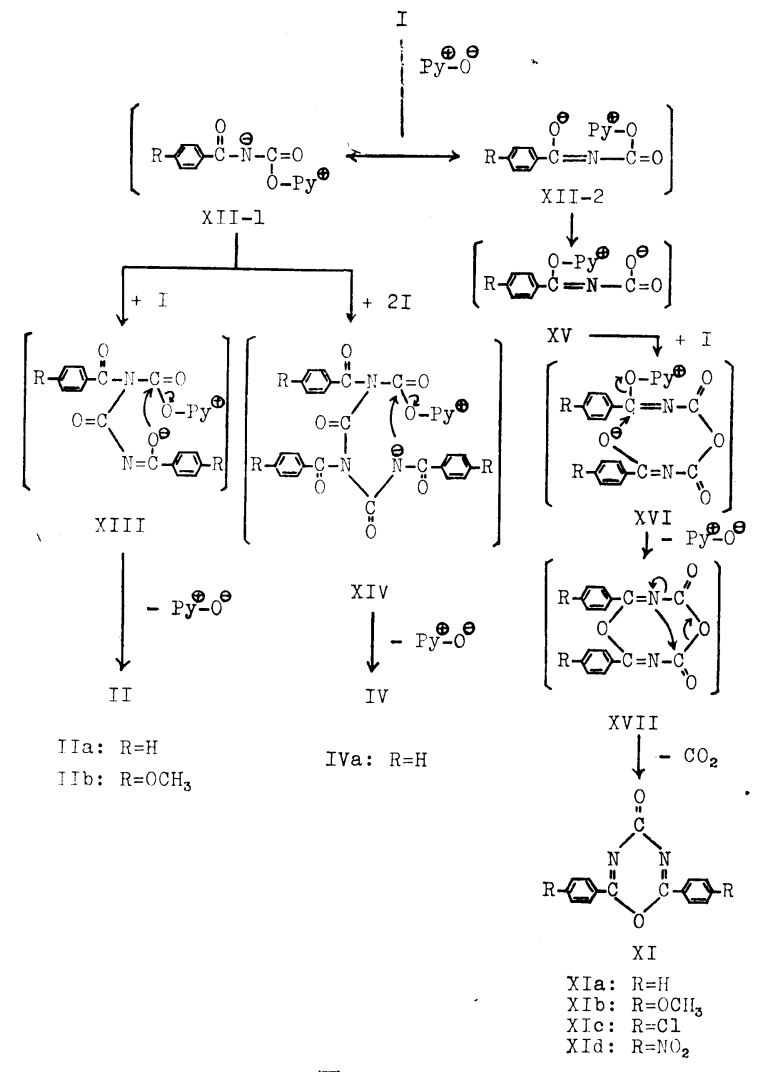

図 6

上述のよ5に二量体 (II) は I -3 と I -4 構造の極性付加体に 対応するので, XII-1 がさらに 1 分子の I に配位した中間体 (XIII) から, 三量体 $(\mathrm{N})$ は 3 分子の I-3 構造の極性付加体であるので XII-1 がさらに 2 分子の I に配位した中間体（XN）から，それぞ れ脱触媒と同時に六員環を形成したものと考学られる。

他方，4-ケト-1,3,5-オキサジアジン（XI）は異性体吕と同様に 2 分子の I-4 構造から 1 分子の二酸化炭素が離脱した構造をも つが，III の生成の場合とは異なる中間体から脱炭酸が起こる。べ ンゾニトリルとI との反応ではXIは生成しないが，XIはベンゾニ トリルと I-4 構造との付加体に対応している。

従って, Xの生成はつぎのような経路によるものと考えられる。 すなわち, XII-2 から XVを経, XV が 1 分子の I-4 構造に配位

*7 アリールインシフナートと $\mathrm{R}_{3} \mathrm{P} \rightarrow \mathrm{O}$ との反応では $\mathrm{R}_{3} \mathrm{P}-\mathrm{O}$
$\phi-\mathrm{N}-\mathrm{C}=\mathrm{O}$ 型中間体を経ることが知られている $(\mathrm{T} . \mathrm{W}$. Campbell ら, J. Am. Chem. Soc., 84, 1493 (1962))。乙 かし, $\mathrm{Py} \oplus-0$ では, 窒素は 5 価になり得ないから饤型の 配位化合物中間体を経ると考えられる。
した中間体 (XV) から脱触媒して八員環中間体（XVI）を形成す る。ここで, 脱触媒の際にアシル基のカルボニルが離脱する。つ いで, XVI から脱炭酸が起きて安定な六員環を形成し，Xが生成 する。

ピリジニウム塩触媒下の反応ではXIのみが生成するが，その経 路は明らかでない。

$2 \cdot 2 \cdot 4$ 塩化第二スズ触媒との反応 塩化第二スズは求電子試 薬であるので, 反応性はイソシアナート基の窒素原子の求核性に 支配される。従って, 電子供与性の大きい置換基をるつ I 程反応 性が強いことが期待され る。ベンゼン中, $80^{\circ} \mathrm{C}$, 20 時間の本触媒との反 応の結果を表 5 に示し た。 表 5 I と塩化第二スズとの反応

\begin{tabular}{cc} 
I & $\begin{array}{c}\text { 告:成物 }(\mathbb{N}) \text { の } \\
\text { 牧率 }(\%)\end{array}$ \\
\hline I a & 25 \\
I b & 60 \\
I c, I d & -
\end{tabular}

予期のように，Ia と Ib はそれぞれ対応する三量体 IVa，IVb を与えるが，電子吸引基をるつ Ic，Id では反応は起らなかった。

本反応に拈ける三量体の生成過程を図 7 に示した。イソシアナ 一ト基の窒素か酸素原子のいずれかに本触媒が配位することが考 えられるが，著者らは窒素原子に配位した構造(XVII)から XX を 経る経路の方がより妥当であろうと推定した。

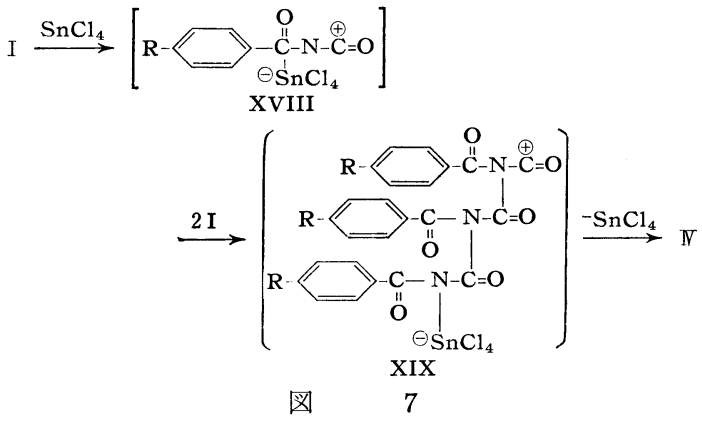

以上の反応の生成物の構造は形式的につぎのようにまとめられ る。すなわち

二量体(II)：I -3 構造と I -4 構造の極性付加生成物

三量体 $(\mathrm{N}): 3$ 分子の $\mathrm{I}-3$ 構造の極性付加生成物

6-ケト-1, 3, 5-オキサジアジン体(III)：2 分子の I -4 構造から

1 分子の脱炭酸縮合生成物

4-ケト-1, 3, 5-オキサジアジン体(III)：I-4 構造からの脱炭酸 生成物（ベンゾニトリル体）と I -4 構造との付加生成物

一般にアリールイソシアナートの反応性は, つぎの共鳴式で示 されるように電子密度の小さいイソシアナート基の炭素原子への 求核試薬の攻撃で説明される。

$$
\phi-\mathrm{N}=\mathrm{C}=\mathrm{O} \leftrightarrow \underset{\text { major }}{\phi-\mathrm{N}=\stackrel{\oplus}{\mathrm{C}}-\stackrel{\ominus}{\mathrm{O}}} \leftrightarrow \underset{\text { minor }}{\phi-\stackrel{\ominus}{\mathrm{N}}-\stackrel{\oplus}{\mathrm{C}}=\mathrm{O}}
$$

しかし，本反応执よび多重結合との付加反応の結果 ${ }^{12)}$ から，ア シルイソシアナートの反応性は, つぎのよ5に表わされてアリー ルイソシアナートなどに比して極めて特異的である。

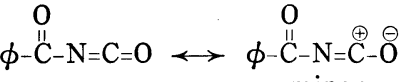

$$
\begin{aligned}
& \text { minor } \\
& 0 \quad \mathrm{O}^{\ominus}
\end{aligned}
$$

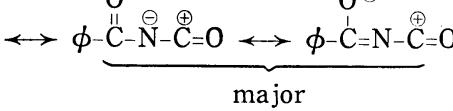

12）日化 18 年会 (1965) にて発表 


\section{3 実験*8}

\section{$3 \cdot 1$ 置換ベンソイルイソシアナート（I）}

ベンザミド類と $7 〜 8$ 倍重量の塩化エチレンの混合物に, 冷却 下よくかきまぜながらアミドに対して $1.1 \sim 1.3 \mathrm{~mol}$ の塩化オキ サリルを徐々に滴下し, 滴下後 30 分間室温でかきまぜる。つい で，3〜4 時間加熱還流すると反応液は透明となり，塩化水素の 発生が止む。反応後, 溶媒を留去し, 減圧蒸留により置換ベンゾ イルイソシアナート（I）が表 1 に示した収率で得られる。なお， I は極めて不安定であるのでエタノールとのウレタン誘導体ある いはジベンジイル尿素誘導体として確認し，表 1 にまとめた。

\section{$3 \cdot 2$ トリエチルアミンとの反応}

代表的な実験操作を挙げる。

Ia $7.0 \mathrm{~g}$ を ーヘヘキサン $20 \mathrm{~g}$ に溶かし, トリエチルアミン 10 滴を加觉て 20 時間加熱還流する。反応後冷却して析出した結晶 を口取。無色結晶, $5.6 \mathrm{~g}$ が得られる。ベンゼンから再結晶する と 2,4 -ジフェニルー6-ケト-1,3,5-オキサジアジン (IIIa), 無色 針状晶, $\mathrm{mp} 184^{\circ} \mathrm{C}$ が $5.0 \mathrm{~g}(79 \%)$ 得られる。

再結晶口液を濃縮し，ベンゼンから再結晶すると無色針状晶の トリベンザミド(Va), $\mathrm{mp} 205^{\circ} \mathrm{C}$ (文献值 ${ }^{13)} 202^{\circ} \mathrm{C}$ ) が $0.5 \mathrm{~g}$ (10 $\%$ ) 得られる。

本触媒と Ia～Id の種々の条件下に扮ける結果は表 2 に示し， 文献末知の化合物については融点, 元素分析值などを表 6 にをと めた。

\section{$3 \cdot 3$ ピリジニウム塩との反応}

ピリジン $8.0 \mathrm{~g}$ に塩化ベンジイル $7.0 \mathrm{~g}$ を加えて室温で 10 分 かきまぜる。ついで，Ia $4.0 \mathrm{~g}$ を加兄て室温で 20 時間反応後， 反応混合液を $10 \%$ 炭酸水素ナトリウム水溶液 $200 \mathrm{ml}$ 中に注入。 沈殿した結晶を口取し，ベンゼンから再結晶すると無色針状晶の 2,6-ジフェニル-4-ケト-1, 3, 5-オキサジアジン(XIa), mp $158^{\circ} \mathrm{C}$ (文献值 $\left.{ }^{10)} 158^{\circ} \mathrm{C}\right)$ が得られる。収量 $2.2 \mathrm{~g}(66 \%) 。$

Ib Id についても同様に反応し, 収率は表 3 に, 各化合物の融 点, 元素分析値などは表 6 にまとめた。

$3 \cdot 4$ ピリジン 1-オキシドとの反応

Ib $3.0 \mathrm{~g}$ を $10 \mathrm{~g}$ のベンゼンに溶かし， ピリジン 1-オキシド $0.5 \mathrm{~g}$ を加えて室温で 20 時間かきまぜる。反応後, 析出した結
晶を口取し，ベンゼンから再結晶すると 2-pーメトキシフェニル -5-p-メトキシベンゾイル-4, 6-ジケト-1, 3, 5-オキサジアジン (IIb), 無色針状晶, $\mathrm{mp} 125 \sim 135^{\circ} \mathrm{C}$ (分解) が得られる。収量 $1.8 \mathrm{~g}(60 \%)$ 。

ピリジン 1-オキシドと Ia～Id との種々の条件下の反応も同様 に行ない，生成物の収率は表 4 に，本反応で生成する文献未知の 化合物の物理的性質, 元素分析值などは表 6 Kとれぞれまとめた。

3.5 塩化第ニスズとの反心

Ib $2.0 \mathrm{~g}$ をべンゼン $10 \mathrm{~g}$ に溶かし, 塩化第二スズ $1.0 \mathrm{~g}$ を加 えて $80^{\circ} \mathrm{C} て ゙ 20$ 時間反応する。反応後, 放冷, 析出した結晶を 口取, ベンゼンから再結晶するとトリ( $p$-メトキシベンゾイル)イ ソシアヌレート (IVb), $\mathrm{mp} 222^{\circ} \mathrm{C}$ (分解) が得られる。収量 1.2 g。

Ia からも同様な反応により $25 \%$ 収率で IVa が得られるが, Ic，Id では反応は起こらない。

\section{$3 \cdot 6$ 二量体 (II) の反応}

i ) IIa $1.0 \mathrm{~g}$ を $10 \mathrm{ml}$ のベンゼンに溶かし，水 10 滴を加 えて 1 時閪加熱睘流寸る。反応後溶媒を減圧下に留去すると，無 色結晶が $0.6 \mathrm{~g}$ 得られる。本物質は赤外スペクトルからジペンッ゙ イル尿素とベンザミドとの混合物であった。

ii）IIa $2.0 \mathrm{~g}$ をジオキサン $10 \mathrm{ml}$ に溶かし，トリエチルアミ ン 5 滴の存在下に 1 時間加熱還流する。反応後, ジオキサンを減 圧留去し，得られた結晶をベンゼンから再結晶すると，トリベン ザミド $(\mathrm{Va}), \mathrm{mp} 205^{\circ} \mathrm{C}, 0.7 \mathrm{~g}$ を得る。な找, 本物質はピリジ ン中 $0.1 \mathrm{~mol}$ のベンザミドと $0.2 \mathrm{~mol}$ の塩化ベンゾイルとの反 応で得た標品と同一物質であった。

\section{3・7 6-ケトー1, 3, 5-オキサジアジン体（III）の反応}

i ） IIIa $1.0 \mathrm{~g} \mathrm{の} 10 \mathrm{ml}$ ベンゼン溶液を 1 時間加熱還流する。 放冷後, 析出した結晶を口取し，ベンがンから再結晶すると無色 針状晶のトリフェニル-S-トリアジン(VIa), $\mathrm{mp} 232^{\circ} \mathrm{C}$ (文献值 ${ }^{14}$ ) $\left.232^{\circ} \mathrm{C}\right)$ が得られる。収量 $0.3 \mathrm{~g}$ 。

な特，本物質は冷却下，多量のクロルスルホン酸中にベンジニ トリルを徐々に滴下して別途合成した標品と同一物質であった。

ii) IIIc $0.2 \mathrm{~g}$ を濃塩酸 $3 \mathrm{ml}$, 水 $13 \mathrm{ml}$ の混合液中, $50^{\circ} \mathrm{C}$ で 1 時間かきまぜる。冷却後，結晶を口取。収量 $0.17 \mathrm{~g}$ 。 ベンゼ ンから再結晶するとジーp-クロルベンザミド，無色針状晶, mp 187

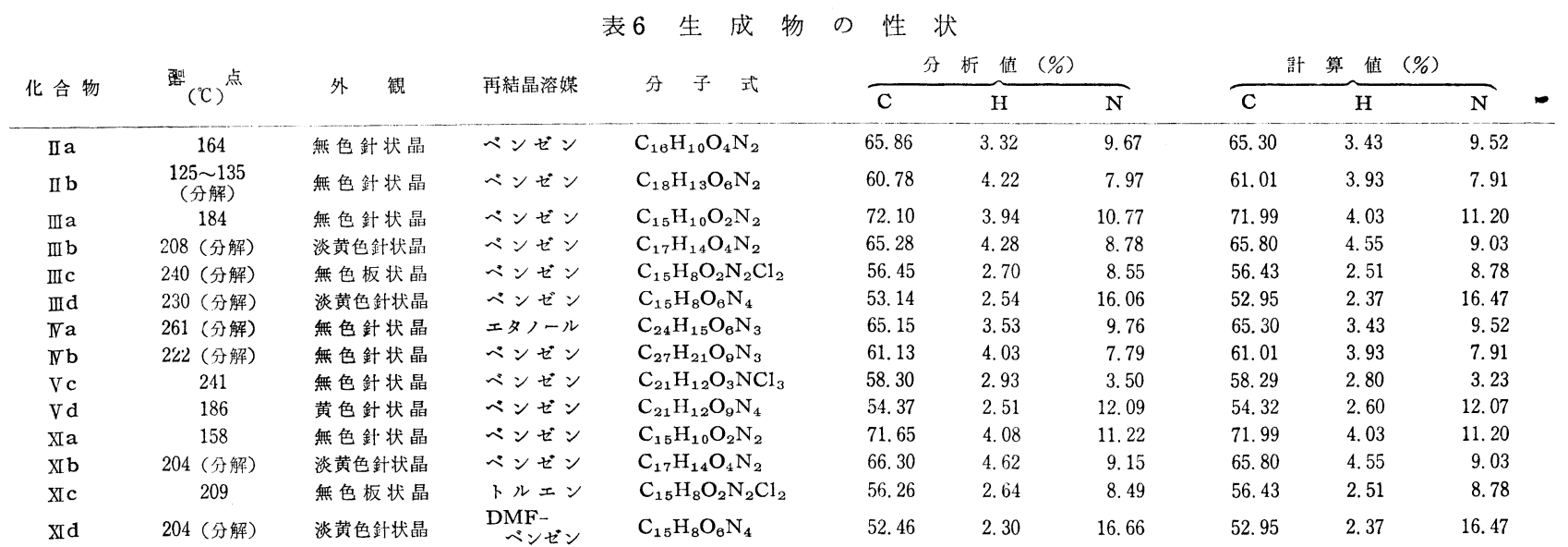

*8 元素分析には九大元素分析センターの諸氏によるねのであ ク，謝意を表する。

13) A. W. Titherly, J. Chem. Soc., 79, 395 (1901).

14) A. H. Cook, D. G. Jones, J. Chem. Soc. 1941, 278. 
${ }^{\circ} \mathrm{C}$ が得られる。

分析值 C $57.30 \%, \mathrm{H} 3.34 \%, \mathrm{~N} 4.86 \%$ $\mathrm{C}_{14} \mathrm{H}_{9} \mathrm{O}_{2} \mathrm{NCl}_{2}$ としての計算値

C $57.14 \%, \mathrm{H} 3.06 \%, \mathrm{~N} 4.76 \%$

な拈，本物質はピリジン中等モルの p-クロルベンザミドと塩化 p-クロルベンゾイルとの反応で別途合成した標品と同一物質であ った。

3.8 4-ケトー1,3，5-オキサジアジン体 (XIc) の加水分解
XIc $0.2 \mathrm{~g}$ を濃塩酸 $3 \mathrm{ml}$ と水 $13 \mathrm{ml}$ の混合液中, $50^{\circ} \mathrm{C}$ で 1 時間かきまぜる。放冷後，結晶を口取すると無色結晶， mp 249 ${ }^{\circ} \mathrm{C}$ (分解) が $0.14 \mathrm{~g}$ 得られる。本物質は $p$-クロルベンゾイルイ ソシアナートと微量の水との反応で別途合成したジ（ $p$-クロルベ ンゾイル）尿素との赤外吸収スペクトルの同定により，同一物質 であった。

(昭和 39 年 12 月, 日本化学会九州 - 中国 - 四国合同常会(高 松), 昭和 40 年 4 月, 日本化学会第 18 年会 (大阪) 発表)

\title{
$\alpha, \beta$-不飽和アルデヒドの電解還元による二量化機構
}

(昭 和 40 年 12 月 6 日 受理)

御園生晃・長哲郎 - 山岸 敬道*1

\begin{abstract}
$\alpha, \beta$-不飽和アルデヒドのアクロレイン, メタクロレインおよびクロトンアルデヒドを $p$-トルェンスルホン酸テトラェチルアン モ二ウム塩 (McKee 塩) 水溶液中抢よび $p$-トルェンスルホン酸（p-TSA）水溶液中で定電位電解還元し，生成物を分離確認し た。いずれの場合もアクロレイン，クロトンアルデヒドに拈いては生成する二量体は，モノマーの $\beta$-炭素間で結合したものが主 であるのに対して, メタクロレインの場合には $\beta$-炭素とカルボニル基の炭素が結合したものが主成分である。しかしアクロレイ ンの $p$-TSA 水溶液中での反応では, $\beta$-炭菜間の結合したもののほかに, $\beta$ 一七ドロキシ体を経た生成物も相当量認められた。

ポーラログラフィーによる測定結果, 単純 LCAO-MO 法により求めた全 $\pi$ 電子密度, フロンティア電子密度などを考虑すると, McKee 塩水溶液中での反応は電極界面でアルデヒドが還元されて生成するアニオンが，他のアルデヒド分子に求核的に付加する ものであり, 一方 $p$-TSA 水溶液中に括いては電極界面でアルデヒドにプロトンが付加して形成する共役酸を経たラジカル間のカ ップリング反応が主に起こると考えられる。
\end{abstract}

\section{1 緒言}

$\alpha, \beta$-不飽和アルデヒドを還元して不飽和または飽和のアルコ ールを得る反応についてはかなり多くの研究がなされているが, 二量化反応特に電解還元による二量化反応に関するものは少ない。 Hibbert, Read'1) はクロトンアルデヒドを $2 \mathrm{~N}$-硫酸水溶液中で 鉛電極，または $25 \%$ 酢酸水溶液中で亜鉛電極を用い $2 \mathrm{~A}$ の電 一流を 8 時間流して電解還元し， $\beta$-炭素間の結合による 1-ホルミ ル-2, 3-ジメチル-1-シクロペンテンを得ている。また Read, Freer ${ }^{2)}$ はアクロレインを硫酸水溶液中鉛電極を用いる $3 \mathrm{~A}$ の電 流で電解還元し，二量体として 1-ホルミルシクロペンテンと 1シタロペンテン-1-イルカルビノールを得ている。二量体の生成 機構としては両者ともに電極界面に生じた発生機の水素が付加し たモノマーラジカルのカップリングによりジアルデヒドを形成し， さらにこれが分子内脱水環化したものと考皇ている。

*1 Akira Misono, Tetsuo OSA, Takamichi YAMAGISHI 東京大学工学部工業化学科: 東京都文京区本郷.

1) H. Hibbert, R. R. Read, J. Am. Chem. Soc., 46, 983 (1924).

2) R. R. Read, R. M. Freer, J. Am. Chem. Soc., 48, 1401 (1926),
著者らはアクロレイン, メタクロレイン, クロトンアルデヒド の一連の $\alpha, \beta$-不飽和アルデヒドを McKee 塩水溶液扎よび $p$ TSA 水溶液中で定電位電解還元し, 反応生成物, ポーラログラ ム, LCAO-MO 法による $\pi$ 電子密度, フロンティア電子密度など から反応機構を検討した結果, McKee 塩水溶液中と $p$-TSA 水 溶液中とでは反応機構が異なり, 前者ではイオン機棈, 後者では ラジカル機構であることを認めた。

\section{2 実験}

\section{$2 \cdot 1$ 試 料}

アクロレインは Shell 社提供のもの, クロトンアルデとドは市 販の 1 級品, メタクロレインはパラホルムアルデヒド $74 \mathrm{~g}$ を $12.6 \%$ の硫酸水溶液 $425 \mathrm{~g}$ に溶解し液温を $95 \sim 100^{\circ} \mathrm{C}$ に保ちな がらプロピオンアルデヒド $108 \mathrm{~g}$ を滴下し, 縮合させて合成 ${ }^{3)}$ たすのをとれぞれ分留して試料とした。表 1 亿各試料の沸点, 純 度を示す。

McKee 塩は Baizer") の方法にしたがって合成した。すなわち 当量の $p$-トルェンスルホン酸エチルとトリエチルアミンを無水

3）三井，北原，宮武，日特公，38-23159.

4) M, M, Baizer, J. Electrochem. Soc., 111, 215 (1964). 